\title{
RT-PCR for detection of bovine parainfluenza virus type 3 (bPIV-3)
}

\author{
RT-PCR para detecção do vírus parainfluenza bovino tipo 3 (bPIV-3)
}

\author{
Rodrigo de Almeida Vaucher ${ }^{1}$, Amauri Braga Simonetti² \& Paulo Michel Roehe ${ }^{2,3}$
}

\begin{abstract}
The RT-PCR technique has been frequentely used for detection of the human parainfluenza virus type 3 (hPIV-3) but the literature is scarce in relation to the bovine parainfluenza virus type 3 (bPIV-3). The aim of this study was to describe a reverse transcriptase polymerase chain reaction (RT-PCR) for detection of bovine parainfluenza virus type 3 (bPIV-3) using degenerate oligonucleotides targeting a conserved region of hemagglutinin-neuraminidase (HN) gene. Reference strain SF-4 and three different brazilian bPIV-3 isolates, besides five viral strains from different sources, were included in this study. Viruses were cultured in MDBK cells under standard conditions. Hemagglutination (HA) test was used for viral titration and a direct immunofluorescence test (DFAT) for isolate screening. In RT-PCR all bPIV-3 isolates showed amplification of an expected 1009 bp fragment of HN gene, as oposed to non PIV-3 viral samples where no amplification was detected. Using SF-4 as positive control, sensitivity of $95 \mathrm{pg}$ cDNA wasachieved. In spite of the low number of bPIV-3 isolates tested, the results obtained in this study point out the potential use of this technique for detection of bPIV-3 in bovine clinical specimens.
\end{abstract}

Keywords: bovine parainfluenza type 3 virus; bPIV-3; RT-PCR; hemagglutinin-neuraminidase (HN) gene, detection.

\section{RESUMO}

A técnica de RT-PCR tem sido freqüentemente utilizada para a detecção do vírus parainfluenza humano tipo 3 (hPIV3), mas a literatura é escassa em relação ao vírus parainfluenza bovino tipo 3 (bPIV-3) .O objetivo deste trabalho foi descrever uma técnica de reação em cadeia pela polimerase, precedida de transcrição reversa (RT-PCR), para a detecção do vírus parainfluenza bovino tipo 3 (bPIV-3), usando oligonucleotídeos degenerados para uma região conservada do gene da hemaglutininaneuraminidase $(\mathrm{HN})$. A amostra-referência SF-4 e três diferentes isolados brasileiros de bPIV-3, além de cinco amostras virais de diferentes origens, foram incluídos neste estudo. Os vírus foram cultivados em células MDBK sob condições padronizadas. O teste de hemaglutinação (HA) foi utilizado para a titulação viral, e o teste de imunofluorescência direta (DFTA) para a triagem dos isolados. Na RT-PCR, todos os isolados de bPIV-3 mostraram amplificação de um fragmento esperado de 1009 pb do gene HN, ao contrário do que aconteceu com as amostras virais não bPIV-3, onde não foi detectada amplificação. Empregando a amostra SF-4 como controle positivo, foi obtida uma sensibilidade de 95 pg de cDNA. Apesar do pequeno número de amostras de bPIV3 testadas, os resultados obtidos neste estudo apontam para o uso potencial desta técnica na deteç̧ão de bPIV-3 em amostras clínicas bovinas.

Descritores: vírus parainfluenza tipo 3; bPIV-3; RT-PCR; gene da hemaglutinina-neuraminidase (HN), detecção.

${ }^{1}$ Programa de Pós-graduação em Microbiologia Agrícola e do Ambiente, Instituto de Ciências Básicas da Saúde, Universidade Federal do Rio Grande do Sul (UFRGS), Porto Alegre, RS/Brasil. ${ }^{2}$ Departamento de Microbiologia, Instituto de Ciências Básicas da Saúde (ICBS-UFRGS), Porto Alegre, RS/Brasil. ${ }^{3}$ Instituto de Pesquisas Veterinárias Desidério Finamor (IPVDF-FEPAGRO), Eldorado do Sul, RS/Brasil. CORRESPONDÊNCIA: A.B. Simonetti [amauri@ufrgs.br; FAX: +55 (51) 3308 4111]. 


\section{INTRODUCTION}

Bovine parainfluenza virus type 3 (bPIV-3) is a Respirovirus, member of Paramyxoviridae family, antigenically related to human parainfluenza virus type 3 (hPIV-3) [7]. It is an important pathogen for animals but can cause disease in humans. In cattle it is associated to the clinical picture known as "shipping fever" [13]. Most cases of respiratory infection with bPIV-3 occur with mild clinical signs. However, more severe infections may be associated with bacterial or virus agents [15]. bPIV-3 has also been associated to abortion in cattle [18].

Laboratory detection of bPIV-3 infections is classically performed by virus isolation in cell culture (gold standard technique). The virus induces a typical cytophatic effect with formation of syncytia and cytoplasmic inclusions [21]. Confirmation of the identity of the virus is usually achieved by HA $[4,14]$ or DFAT [7] tests, but they are not capable to discriminate viral serotypes and may produce falsenegative results.

The RT-PCR has been used as an alternative procedure for detection of human PIV-3 (hPIV-3) in nasal secretions or for confirming the identity of isolates [9]. Oligonucleotides based on the highly conserved sequences of the hemagglutinin (HN) and fusion protein genes have generally been used for diagnostic purposes [10,16,21]. RT-PCR for hPI-3 has been associated to other diagnostic PCRs in multiplex [1,8] and hexaplex [11] formats and have been used to detect a number of viruses and other agents in clinical specimens. However, to our knowledge, one report was published for detection and differentiation of bPIV-3 strains by amplification and sequencing of the HN gene studying Northern American viral strains and Russian isolates [22]. The aim of the present study was to develop a RT-PCR for detection of bPIV-3 and evaluate the test on three Brazilian bPIV-3 isolates.

\section{MATERIALS AND METHODS}

\section{Viruses and cells}

The bPVI-3 strain (National Veterinary Laboratories Service - USA), named SF-4, was kindly provided by Dr. Silvia Sardi from Federal University of Bahia (Salvador, BA, Brazil). After four passages in MDBK cells, the virus was used as positive control in all tests performed. As negative control uninfected MDBK cells were used.
Other five viral strains were included in the RT-PCR for specificity tests: human parainfluenza virus 1 and 2 (hPIV-1 and hPIV-2), canine distemper virus $^{1}$ (CDV - Lederle strain); bovine herpesvirus type-1 (BHV-1, kindly supplied by Instituto Nacional de Tecnologia Agropecuária, Balcarce-Argentina, and equine influenza virus (H2N2) provided by the Laboratory of Virology-Oswaldo Cruz Foundation (FIOCRUZ/RJ-Brazil).

Three Brazilian isolates were analysed by RTPCR in this study. Two isolates (DIO and PG1775) were originated from nasal secretions of bovines with clinical symptoms from different states of Brazil (Rio Grande do Sul and Goiás, respectively). Viruses were multiplied in Madin-Darby Bovine Kidney cells (MDBK, ATCC, CCL-22) following standard procedures $[12,19]$. The third brazilian isolate (CRIB) was obtained from an unintentionally contaminated culture of bovine cells, gently provided by Dr. Eduardo Flores (Laboratório de Virologia - Faculdade de Veterinária da Universidade Federal de Santa Maria - Santa Maria, RS).

\section{Viral multiplication and titration}

Viruses were cultured in MDBK cells in 25 $\mathrm{cm}^{2}$ flasks in Eagle's Minimal Essential Medium² (EMEM) supplemented with $8 \%$ fetal bovine serum ${ }^{2}$ (FBS) and $10 \mathrm{mg} / \mathrm{L}$ enrofloxacin. ${ }^{3}$ Cells were maintained in closed bottles at $37^{\circ} \mathrm{C}$ according to usual methods [3]. Titrations were carried out as described [5], adapted to 96 wells plates incubated in a $5 \% \mathrm{CO}_{2}$ atmosphere. Haemagglutination tests (HA) were performed as reported previously [6] with the reference strain SF-4 as positive control. Titrations were expressed as tissue culture $50 \%$ infectious doses $\left(\mathrm{TCID}_{50}\right)$.

\section{Hemagglutination test (HA)}

Hemagglutination test was performed as described previously [12]. Results were expressed as hemagglutinating units $/ 50 \mu \mathrm{L}$ (HAU/50 $\mu \mathrm{L}$ ).

\section{Direct fluorescence antibody test (DFAT)}

Isolates were first tested by DFAT as described previously [12] with few modifications. Briefly, in 6 well plates containing sterile coverslips (24 x $24 \mathrm{~mm})$ $200 \mu \mathrm{L}$ of trypsinized ${ }^{1}(0.1 \%$ trypsine) MDBK cells and $800 \mu \mathrm{L}$ of serum-free E-MEM were added. After incubation for 24 hours at $37^{\circ} \mathrm{C}$ in $5 \% \mathrm{CO}_{2}, 50 \mu \mathrm{L}$ of viral samples were inoculated at concentration of approximately $10^{5.0} \mathrm{TCID}_{50}$ and the plate was incubated for 72 hours to produce cytophatic effect 
(CPE). Supernatants were discarded and cells were fixed in acetone for 10 minutes. Following 3 washes in PBS (116 mM NaCl, $20.8 \mathrm{mM} \mathrm{Na}_{2} \mathrm{HPO}_{4}, 2.9 \mathrm{mM}$ $\mathrm{KH}_{2} \mathrm{HPO}_{4}, \mathrm{pH} 7.4$ ), coverslips were incubated with $20 \mu \mathrm{L}$ of fluorescein labelled anti-bPIV-3 monoclonal antibody ${ }^{4}$ diluted 1:5 in PBS, for 30 minutes at $37^{\circ} \mathrm{C}$. Subsequently, coverslips were washed 3 times with PBS and observed under ultraviolet illumination ${ }^{5}$. SF4 reference strain was used as positive control for bPIV-3 and an anti-bovine herpesvirus monoclonal antibody as negative control.

\section{Selection and synthesis of oligonucleotides}

The sequences of the gene coding for hemagglutinin-neuraminidase $(\mathrm{HN})$ protein of SF-4 strain, bPVI3 and hPIV-3 were obtained from GenBank database (accession numbers: AF178655, AF178654, D84095, NC001796, ABO12132, M21649 and $\mathrm{Z} 11575)$. These sequences were aligned using the program CLUSTAL W - Version 3.0 [20]. The degenerate oligonucleotides were selected using the program VECTOR NTI - Version 4.0 (InforMax, Inc.) and synthesized $(50 \mathrm{nmol})$ by Invitrogen. ${ }^{6}$ Data on primers selected for RT-PCR are shown in Table 1.

DNA extraction from bovine herpesvirus type 1 (BHV-1)

To test RT-PCR specificity, DNA extraction of BHV-1 was carried out with phenol-chloroform as described elsewhere [17].

RNA isolation, cDNA synthesis and PCR amplification

Total viral RNA was extracted from viral stocks with Trizol ${ }^{6}$ according to manufacturer's instructions. cDNA synthesis of the genomic RNA and PCR amplification were performed with P3 and P6 primers (Table 1). cDNA concentration was estimated spectrophotometrically at $240 \mathrm{~nm}^{7}$.

Viral RNA $(3-5 \mu \mathrm{g})$ was reverse-transcribed using 200 units of M-MLV reverse transcriptase ${ }^{6}$ according to the manufacturer's instructions and amplified by PCR using Taq DNA polymerase ${ }^{6}$ (5 units/ $\mu$ l) in PCR buffer $(3 \mathrm{mM} \mathrm{MgCl}, 75 \mathrm{mM} \mathrm{KCl}$, $50 \mathrm{mM}$ Tris- $\mathrm{HCl}, \mathrm{pH} 8.3,1 \mathrm{mM}$ each dNTP) in a final volume of $50 \mu$. Thermal cycling conditions were: 1 cycle at $96^{\circ} \mathrm{C}$ for $2 \mathrm{~min} ; 35$ cycles at $94^{\circ} \mathrm{C}$ for $1 \mathrm{~min}$, $44^{\circ} \mathrm{C}$ for $1 \mathrm{~min}$ and $72^{\circ} \mathrm{C}$ for $1 \mathrm{~min}$, followed by 1 final incubation at $72^{\circ} \mathrm{C}$ for $7 \mathrm{~min}$. PCR products were examined by electro-phoresis in $1.5 \%$ agarose gels and visualized under a UV light after ethidium bromide staining. As controls, cDNA from SF-4 reference strain (positive) and cDNA from uninfected MDBK cells (negative) were used.

\section{Estimation of RT-PCR detection limit}

The detection limit of RT-PCR was evaluated by: 1) Titration of the reference strain SF-4 followed by individual RNA isolation, cDNA synthesis and PCR amplification; 2) Amplification of cDNA obtained from SF-4 strain using dilutions from 1:10 to 1:20000 with initial cDNA concentration of $475 \mathrm{ng} / \mu \mathrm{L}$. Amplicons were visualized in $1.5 \%$ agarose gels.

\section{Estimation of RT-PCR analytical specificity}

The specificity of RT-PCR was analysed by RT-PCR amplification of SF-4 strain (positive control) and hPIV-1, hPIV-2, Lederle, BHV-1 and H2N2 strains, at the same conditions described earlier.

\section{RESULTS}

Titration results for DIO, PG1775 and CRIB isolates were $10^{5.25} \mathrm{TCID}_{50}, 10^{6.0} \mathrm{TCID}_{50}$ and $10^{4.75}$ $\mathrm{TCID}_{50}$, respectively. When performed by HA titration results were $16 \mathrm{HAU} / 50 \mu \mathrm{L}, 32 \mathrm{HAU} / 50 \mu \mathrm{L}$ and 8 HAU/50 $\mu \mathrm{L}$, respectively.

The RT-PCR described here, using primers representing part of bPIV-3 hemagglutinin-neuraminidase gene $(\mathrm{HN})$, amplified a fragment of approximately 1009 bp with material extracted from SF-4

Table 1. Primers representing part of bPIV-3 hemagglutinin-neuraminidase gene (HN) used for RT-PCR and sequencing.

\begin{tabular}{ccccc}
\hline Oligonucleotides & $\begin{array}{c}\text { Nucleotide } \\
\text { Location }{ }^{\mathrm{a}}\end{array}$ & Sequence $\left(5^{\prime} \rightarrow 3^{\prime}\right){ }^{\mathrm{b}}$ & References & Amplicon \\
\hline P3 (+) & $7088-7108$ & ACAAGYRCTTCTYYACAATTCAG & *Stokes et al., 1992 & 1009 bp \\
P6 (-) & $8076-8096$ & GTAATTTYRCTYRTGCCAACTTG & $*$ Storey et al., 1987 & \\
\hline
\end{tabular}

(+) Direct and (-) reverse oligonucleotides. * Adapted oligonucleotides. ${ }^{a}$ Location of the nucleotides was based on the sequence of the complete gene of the bPIV-3, SF-4 strain. ${ }^{\mathrm{b}} \mathrm{YR}=\mathrm{A} / \mathrm{G}$ and $\mathrm{YY}=\mathrm{C} / \mathrm{T}$. 


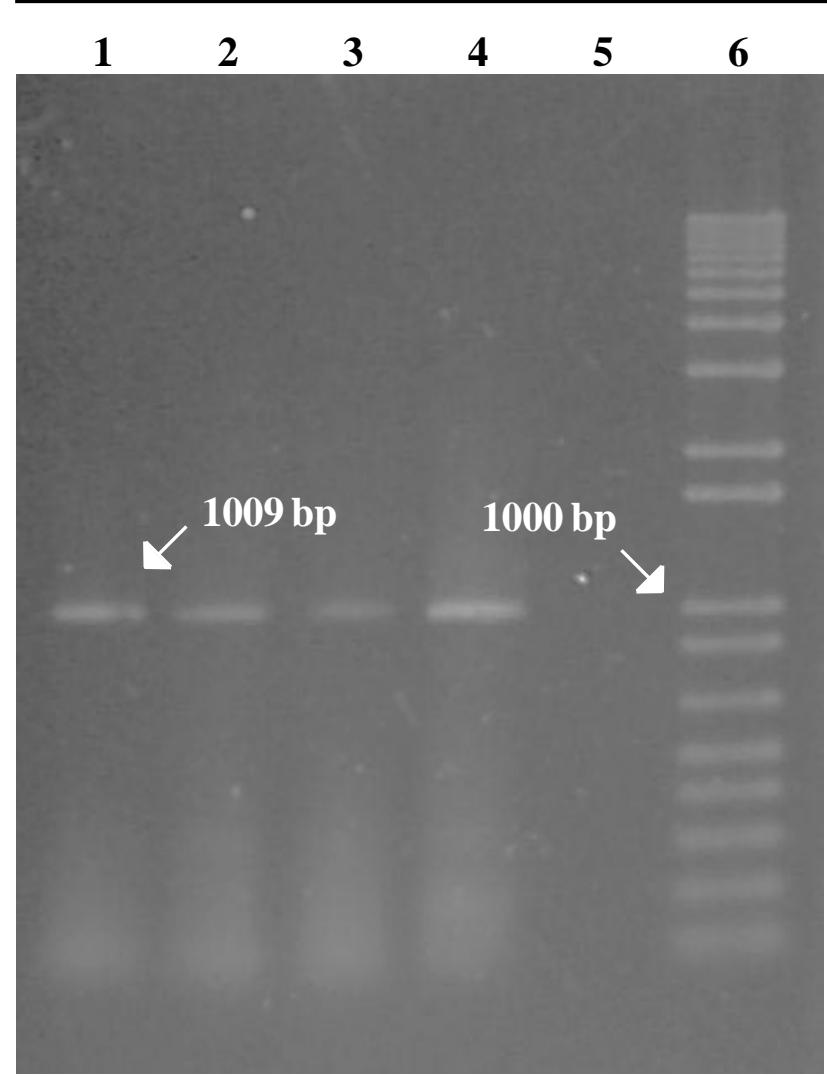

Figure 1. RT-PCR amplification. Results showing 1009 bp fragments amplified from cDNA of SF-4 reference strain and three brazilian isolates using $\mathrm{P} 3 / \mathrm{P} 6$ primers that represent part of bPIV-3 hemagglutinin-neuraminidase gene $(\mathrm{HN})$. PCR products were analysed in $1.5 \%$ agarose gel electrophoresis. Lane 1: SF-4 reference strain; Lane 2: DIO isolate; Lane 3: PG1775 isolate; Lane 4: CRIB isolate; Lane 5: negative control; Lane 6: molecular size marker (1kb DNA Ladder, Invitrogen).

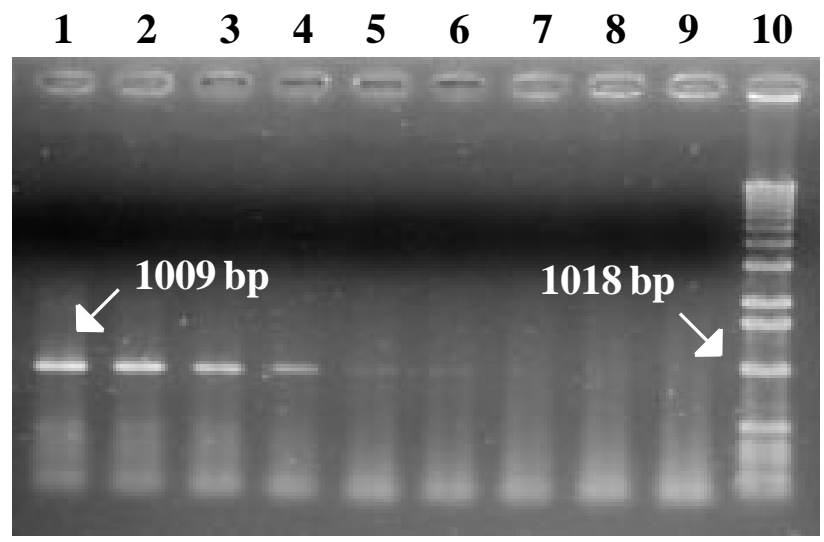

Figure 2. Detection limit of RT-PCR. Dilution series of SF-4 strain cDNA (475 ng/ $\mu \mathrm{L})$ were amplified by RT-PCR (1009 bp amplicon) and analysed by $1.5 \%$ agarose gel electrophoresis. Lanes: 1) $475 \mathrm{ng} / \mu \mathrm{L}$; 2) $47,5 \mathrm{ng} / \mu \mathrm{L}$; 3 ) 4,75 ng/ $\mu \mathrm{L}$; 4) $475 \mathrm{pg} / \mu \mathrm{L}$; 5) $190 \mathrm{pg} / \mu \mathrm{L}$; 6) $95 \mathrm{pg} / \mu \mathrm{L}$; 7) $47,5 \mathrm{pg} / \mu \mathrm{L}$; 8) $24 \mathrm{pg} / \mu \mathrm{L}$; 9) Negative control; 10) Molecular size marker (1 kb DNA Ladder, Invitrogen).

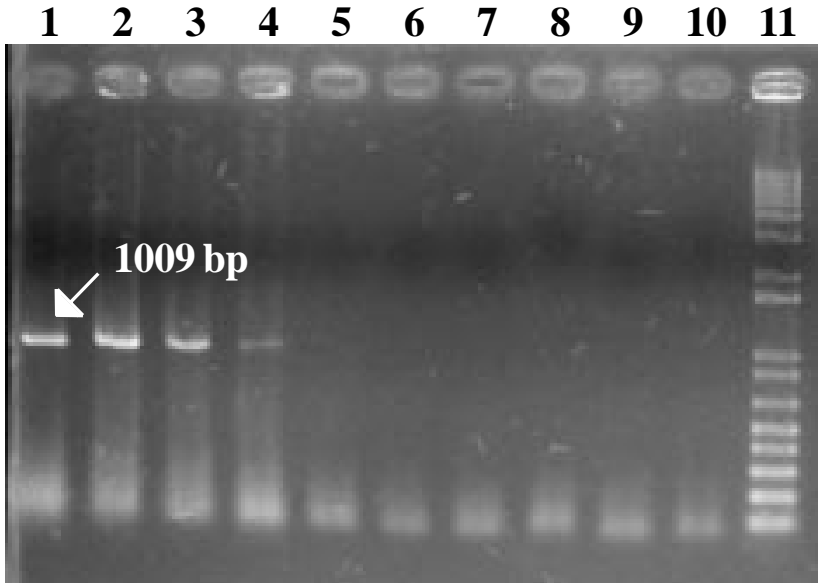

Figure 3. RT-PCR specificity. Results showing 1009 bp fragments amplified from cDNA of SF-4, DIO, PG1775 and CRIB isolates and no fragments amplified in cDNA from five different virus. PCR products were analysed in $1.5 \%$ agarose gel electrophoresis. Lane 1: SF-4 reference strain; Lane 2: DIO isolate; Lane 3: PG1775 isolate; Lane 4: CRIB isolate; Lane 5: hPIV-1; Lane 6: hPIV-2; Lane 7: Canine Distemper Virus (Lederle strain); Lane 8: Equine Influenza Virus (H2N2); Lane 9: Bovine Herpesvirus (BHV-1); Lane 10: negative control; Lane 11: molecular size marker (1kb DNA Ladder, Invitrogen).

reference strain and from DIO, PG1775 and CRIB isolates. No amplification was detected with the negative control (uninfected MDBK cells) (Figure 1).

To test the limit of detection by titration of the reference strain SF-4, the RT-PCR displayed amplification up to $140 \mathrm{TCID}_{50}$ (not shown). After serial dilutions of an initial SF-4 cDNA concentration of $475 \mathrm{ng} / \mu \mathrm{L}$, visible amplification was observed up to the dilution 1:5000 corresponding to approxima-tely $95 \mathrm{pg} / \mu \mathrm{L}$ of cDNA (Figure 2).

In RT-PCR specificity tests it was observed amplification of $1009 \mathrm{bp}$ fragments corresponding to SF-4 reference strain and DIO, PG1775 and CRIB isolates, whereas no amplification was detected in cDNA from five different viruses (Figure 3).

\section{DISCUSSION}

In human clinical specimens the RT-PCR has been used as an alternative procedure for detection of PIV-3 using oligonucleotides based on highly conserved sequences of structural genes of hPIV-3 coding for the HN protein $[9,11,16]$. Corne et al. [8] achieved a sensitivity of $1 \mathrm{TCID}_{50}$ for a multiplex RTPCR whereas Aguilar et al. [1] reported 32 TCID $_{50}$, both for hPIV-3. In our study, sensitivity of RT-PCR corresponded to $140 \mathrm{TCID}_{50}$ and the detection limit 
was approximately $100 \mathrm{pg} / \mu \mathrm{L}$ after cDNA dilution. This apparent discrepancy is probably due to the different experimental conditions used by the authors including cell lineages and methods for sensitivity determination.

Within the conditions employed in this study the specificity of the RT-PCR was $100 \%$, compared to that obtained for hPIV-3 by Fan et al. [11] and Corne et al. [8] who found $98 \%$ and $100 \%$, respectively. Although including only five viral samples to check the specificity of our method, it is worthy to stress that two of them were human parainfluenza viruses (hPIV1 and hPIV-2) which emphasizes the specificity of the oligonucleotides used, since there is a great similarity among PIV-3 strains [2].

Recently, amplification of gene HN fragment was utilized for identification and strain differentiation of bovine parainfluenza-3 virus in Northern American viral strains and Russian isolates [22]. This study revealed 2 genetic groups among the investigated virus strains and isolates: group 1 was made up of Northern American viral strains and of Russian isolates, whose primary structure has a high level of homology to the primary SF-4/32 strain structure; group 2 including the virus' Russian isolates with high level of homology to Japanese strains' sequences. With the improvement of the RT-PCR technique described here it could be possible to carry out similar studies in Brazil, comparing viral samples from different regions.

\section{CONCLUSION}

The RT-PCR presented in this study is adequate for detection of bPIV-3 from cell cultures and this technique can be improved for viral detection in aspirates or swabs from animals, contributing to diagnosis and epidemiological studies on bPIV-3.

Acknowledgements. The authors would like to thank Drs. Sílvia Sardi and Eduardo Flores for supplying the SF-4 and CRIB isolates, respectively. Our gratitude to MSc. Celir Straliotto from Laboratório Central do Rio Grande do Sul (LACEN/RS-Brazil) for supplying the human parainfluenza virus samples. P.M. Roehe is a CNPq research fellow. R.A.Vaucher was recipient of MSc. scholarship from CAPES. The authors wish to thank the Brazilian Institutes $\mathrm{CNPq}$ and CAPES for financial support.

\section{SOURCES AND MANUFACTURERS}

${ }^{1}$ BIOVET S/A, Vargem Grande Paulista, São Paulo, Brasil. ${ }^{2}$ E-MEM, Gibco-BRL, U.S.A.

${ }^{3}$ Baytril, Bayer, São Paulo.

${ }^{4}$ Central Veterinary Agency, Weybridge, UK.

${ }^{5}$ Axiolab, Carl Zeiss, Germany.

${ }^{6}$ Invitrogen, Carlsbad, U.S.A.

${ }^{7}$ Ultrospec® II - LKB Biochrom LTD, UK.

\section{REFERENCES}

1 Aguilar J.C., Pérez-Breña M.P., Garcia M.L., Cruz N., Erdman D.D. \& Echevarria J.E. 2000. Detection and identification of human parainfluenza viruses 1,2,3 and 4 in clinical samples of pediatric patients by multiplex reverse transcriptionPCR. Journal of Clinical Microbiology. 38: 1191-1195.

2 Bailly J.E., McMauliffe J.M., Skiadopoulos M.H., Collins P.L. \& Murphy B.R. 2000. Sequence determination and molecular analyses of two strains of bovine parainfluenza virus type 3 that are attenuated for primates. Virus Genes. 20: 173-182.

3 Butler M. \& Dawson M. 1992. Cell culture. London: Blackwell Scientific, pp.247-.263.

4 Canchola J.G., Chanock R.M., Jeffries B.C., Christmas E.E., Kim H.W., Vargosko A.J. \& Parrott R.H. 1965. Recovery and identification of human myxoviruses. Bacteriological Reviews. 29: 496-503.

5 Carbrey E. A., Stewart W. \& Kresse J.L 1971. Recommended standard laboratory techniques for diagnosing infectious bovine rhinotracheitis, bovine diarrhea virus and shipping fever (Parainfluenza 3). Proceedings of U. S. A. Health Association. 75: 629-648.

6 Chanock R.M. \& Johnson M.D. 1989. Parainfluenza viruses. In: Schmidt N.J., Emmons R.W.(Ed). Diagnostic Procedures for Viral and Rickettsial Diseases. 6th edn. New York: American Public Health Association Publications, pp.470-483.

7 Collins P.L., Chanock R.M. \& McChinstosh K. 1996. Parainfluenza virus. In.: Fields B.N.(Ed). Fields Virology. 3rd edn. Philadelphia: Lippincott-Raven, v.1, pp. 1205-1223.

8 Corne J.M., Green S., Sanderson G., Caul E.O. \& Johnston S.L. 1999. A multiplex RT-PCR for the detection of parainfluenza viruses 1-3 in clinical samples. Journal of Virological Methods. 82: 9-18.

9 Echevarría J.E., Erdman D.D., Meissner H.C. \& Anderson L. 2000. Rapid molecular epidemiologic studies of human parainfluenza viruses based on detect sequencing of amplified DNA from a multiplex RT-PCR assay. Journal of Virological Methods. 88:105-109. 
10 Fan J. \& Henrickson K.J. 1996. Rapid diagnosis of human parainfluenza virus type 1 infection by quantitative reverse transcription-PCR-enzyme hybridization assay. Journal of Clinical Microbiology. 34: 1914-1917.

11 Fan J., Henrickson K.J. \& Savatski L.L. 1998. Rapid Simulataneous Diagnosis of infections with respiratory syncytial viruses A and B, influenza viruses A and B, and human parainfluenza Virus Tipes 1, 2 and 3 by Multiplex Quantitative Reverse Transcription - Polymerase Chain Reaction - Enzyme Hybridization Assay (Hexaplex). Clinical Infectious Diseases 26: 1397-1402.

12 Gonçalves D.A., Spilki F.R., Chiminazzo C., Oliveira M.A., Franco A.C. \& Roehe P.M. 2003. Isolamento do vírus parainfluenza bovino tipo 3 no Rio Grande do Sul, Brasil. Ciência Rural, Santa Maria. 33: 953-956.

13 Henrickson K.J. \& Savatski L.L. 1997. Antigenic structure, function, and evolution of the hemagglutinin-neuraminidase protein of human parainfluenza virus type 1. Journal of Infectious Diseases. 176: 867-875.

14 Herrmann E.C. \& Hable K.A. 1970. Experiences in laboratory diagnosis of parainfluenza viruses in routine medical practice. Mayo Clinic Proceedings. 45: 177-188.

15 Kapil S. \& Basaraba R.J. 1997. Infectious bovine rhinotracheitis, parainfluenza-3, and respiratory coronavirus. Veterinary Clinics of North America and Food Animal Practice. 13: 455-469.

16 Karron R.A., Froehlich J.L., Bobo L., Belshe R.B. \& Yolken R.H. 1994. Rapid detection of parainfluenza type 3 virus RNA in respiratory specimens: use of reverse transcription-PCR-enzyme immunoassay. Journal of Clinical Microbiology. 32: 484-488.

17 Sambrook J., Fritsh E.F. \& Maniatis T. 1989. Molecular Cloning: a Laboratory Manual. 2 nd edn. New York: Cold Spring Habor Laboratory, v.3., pp. E3-E7.

18 Sattar S.A., Bohl E.H. \& Senturk M. 1965. Viral causes of bovine abortion in Ohio. Journal of American Medical Association. 147: 1207-1210.

19 Silva A.D., Gonçalves D.A., Spilki F.R., Chiminazzo C., Oliveira M.A., Franco A.C. \& Roehe P.M. 2002. Isolamento do vírus parainfluenza tipo $3 \mathrm{em}$ aborto bovino no Estado de Goiás (GO). In: Congresso Brasileiro de Medicina Veterinária (Gramado, RS). pp.29.

20 Thompson J.D., Higgins D.G. \& Gibson T.J. 1994. CLUSTAL W: improving the sensitivity of progressive multiple sequence alignment through sequence weighting, positions-specific gap penalties and weight matrix choice. Nucleic Acids Research. 22: 4673-4680.

21 Waner J.L. 1999. Parainfluenza Viruses. In.: Murray P.R. (Ed.). Manual of Clinical Microbiology. 7th edn. New York American Society for Microbiology, pp. 1157-1197.

22 Vecherov A.E., Aianot P.K., Timina A.M. \& Lisitsin V.V. 2003. Detection and differentiation of the bovine parainfluenza3 virus strains studied by amplification and sequencing of the HN gene. Vopr Virusol. 48:46-9. (russian) 